\title{
METHODOLOGICAL FOUNDATIONS OF ANALYSIS AND FORECASTING OF GAS CONSUMPTION IN THE SYSTEM OF ENERGY BALANCE OF UKRAINE BY USING THE GROUP METHOD OF DATA HANDLING
}

This research deals with issues of gas consumption in Ukraine. The dynamics of consumption of gas is analysed and proposed guidelines for the efficient production, consumption and import of gasin Ukraine. Constructed and developed predictive models of gas consumption in Ukraine through the use of modern software and using the group method of data handling, which allowed building adequate predictive models of gas consumption in the system of Ukraine's energy balance. Researched and forecasted scenarios of gas consumption in the Ukraine.

The problem of efficient use of energy resources is critical for sustainable economic development against the backdrop of energy saving national economy depends on energy imports, on the one hand, and rising prices for these resources. The basic foundation of the formation energy system of Ukraine is to build forecasting scenarios for different types of energy and different criteria for effective use of energy resources. Solving this problem is not only with ensuring energy security, but also with the level of development of regions of Ukraine and ensuring quality of life.

Prediction of gas consumption in Ukraine today is an extremely important issue of strategic importance since conducted through analysis and building predictive models will be possible to develop guidelines for the efficient production and consumption of gas across Ukraine as a whole.

Keywords: energy conservation; energy efficiency; energy balance; energy statistics.

Formulation of the problem. Construction and development of predictive models for the consumption of gas in Ukraine by using the group method of data handling and by using modern software.

Analysis of recent research and publications. In [2] is shown the comparison as previously proposed and those developed methods for short-term forecasting of gas consumption: regression analysis, neyronnoh networks and fuzzy neural networks. Intensive development of software products aimed at predicting gas [3], theory and practice modeling, forecasting processes in new ways raises the question of developing a new multi multivariate predictive model that will take into account more factors and performance unlike other predictive models. In the article forecasting scenarios of gas consumption in Ukraine are build by using group method of data handling.

The aim of the study. The study aims to develop methodological provisions for forecasting the gas consumption in Ukraine by using the group method of of data handling.

The main material of the research. The level of energy has a decisive impact on the economy of the state, resolving social problems and living standards of citizens. Changes in energy prices immediately reflected in all industries, and the rest, the price of the final product. Therefore, instead of quantitative objectives of energy development, which was followed by Ukraine's economy in recent decades, energy has to go to power sustainable economic development, focused on that now developed countries. The said research leads scientists to balance the energy balance of Ukraine, which determined the relevance of the work. In the traditional understanding of energy balance is the ratio between the extraction (production) and consumption of different types of energy resources.

At the heart of the development of fuel and energy balance is a set of strategic statements of economic development, the definition of forecast volumes of energy consumption, based on adopted policies to increase energy efficiency, the development of fuel and energy complex and evaluating opportunities extraction and production of fuel and energy, as well as the formation of areas of import - export policy and determine the volume of purchase and sale of energy.

One of the mathematical methods of forecasting is group method of data handling, which allows you to build adequate predictive models of energy consumption in the system of Ukraine's energy balance.

With the help of a group of data handling and by using modern software were built predictive models of consumer energy resources of the system energy balance of Ukraine:

1. Predictive system model, 2 lags:

$$
\begin{aligned}
& \mathrm{Y}(1)=0,3197 * \mathrm{Y} 1(-1)+0,7452 * \mathrm{Y} 1(-2)+0,0036 * \mathrm{Y} 3(-2) \\
& \mathrm{Y}(2)=45.4376+0,3214 * \mathrm{Y} 3(-1)+0.1638 * \mathrm{Y} 3(-2) \\
& \mathrm{Y}(3)=95.9092-2.2548 * \mathrm{Y} 1(-2)
\end{aligned}
$$


Initial data for gas production

\begin{tabular}{|c|c|c|c|}
\hline \multirow{2}{*}{ Year } & $\begin{array}{c}\text { Gas production, } \\
\text { billion } \mathrm{m}^{3}\end{array}$ & $\begin{array}{c}\text { Consumption of gas, } \\
\text { billion } \mathrm{m}^{3}\end{array}$ & $\begin{array}{c}\text { Imports of gas, } \\
{\text { billion } \mathrm{m}^{3}}^{*}\end{array}$ \\
\cline { 2 - 4 } & $\mathrm{Y} 1$ & $\mathrm{Y} 2$ & Y3 \\
\hline 2006 & 21,5 & 75,1 & 54,1 \\
\hline 2007 & 22,4 & 73,6 & 52,8 \\
\hline 2008 & 23,8 & 71,3 & 47,5 \\
\hline 2009 & 24,2 & 69,5 & 45,4 \\
\hline 2010 & 25,5 & 67,6 & 42,1 \\
\hline 2011 & 26,3 & 66,2 & 39,3 \\
\hline 2012 & 27,9 & 65,5 & 37,2 \\
\hline 2013 & 28,1 & 64,9 & 33,6 \\
\hline 2014 & 29,7 & 63,7 & 31,3 \\
\hline 2015 & 31,1 & 62,4 & \\
\hline
\end{tabular}

Results of approximation and forecast for the next 5 years.

The first indicator $\mathrm{Y} 1-$ Gas production, billion $\mathrm{m}^{3}$ is given in table 2 .

Gas production, billion $\mathrm{m}^{3}$

\begin{tabular}{|c|c|c|c|c|c|c|c|c|c|}
\hline Year & 2006 & 2007 & 2008 & 2009 & 2010 & 2011 & 2012 & 2013 & 2014 \\
\hline Table & 21,5 & 22,4 & 23,80 & 24,20 & 25,50 & 26,30 & 27,90 & 28,10 & 29,70 \\
\hline Forecast & - & - & 23,38 & 24,36 & 25,38 & 26,44 & 27,53 & 28,65 & 29,81 \\
\hline
\end{tabular}

Continuation of Table 2

\begin{tabular}{|c|c|c|c|c|c|c|}
\hline Year & 2015 & 2016 & 2017 & 2018 & 2019 & 2020 \\
\hline Table & 31,10 & - & - & - & - & - \\
\hline Forecast & 31,02 & 32,20 & 10.30 & 27,39 & 16,78 & 25,86 \\
\hline
\end{tabular}

The second indicator $\mathrm{Y} 2$ - Consumption of gas, billion $\mathrm{m}^{3}$ is given in table 3 .

Consumption of gas, billion $\mathrm{m}^{3}$

\begin{tabular}{|c|c|c|c|c|c|c|c|c|c|}
\hline Year & 2006 & 2007 & 2008 & 2009 & 2010 & 2011 & 2012 & 2013 & 2014 \\
\hline Table & 75,1 & 73,6 & 71,30 & 69,50 & 67,60 & 66,20 & 65,50 & 64,90 & 63,70 \\
\hline Forecast & - & - & 71,27 & 69,33 & 67,80 & 66,76 & 65,68 & 64,58 & 63,44 \\
\hline
\end{tabular}

Continuation of Table 3

\begin{tabular}{|c|c|c|c|c|c|c|}
\hline Year & 2015 & 2016 & 2017 & 2018 & 2019 & 2020 \\
\hline Table & 62,40 & - & - & - & - & - \\
\hline Forecast & 62,26 & 61,00 & 54,74 & 81,01 & 68.64 & 72,62 \\
\hline
\end{tabular}

The third indicator $\mathrm{Y} 3$ - Imports of gas, billion $\mathrm{m}^{3}$ is given in table 4 .

Imports of gas, billion $\mathrm{m}^{3}$

\begin{tabular}{|c|c|c|c|c|c|c|c|c|c|}
\hline Year & 2006 & 2007 & 2008 & 2009 & 2010 & 2011 & 2012 & 2013 & 2014 \\
\hline Table & 54,1 & 52,8 & 47,5 & 45.4 & 42,1 & 40,3 & 39.6 & 37,3 & 33.6 \\
\hline Forecast & & & 48,49 & 45,56 & 42,61 & 40,02 & 37,64 & 35,47 & 33,48 \\
\hline
\end{tabular}




\begin{tabular}{|c|c|c|c|c|c|c|}
\hline Year & 2015 & 2016 & 2017 & 2018 & 2019 & 2020 \\
\hline Table & 31,3 & - & - & - & - & - \\
\hline Forecast & 31,66 & 29,79 & 19,39 & 21,27 & 19,49 & 18,89 \\
\hline
\end{tabular}

Interconnection between imports of gas and petroleum:

$$
\begin{aligned}
& \mathrm{Y} 1=0.9017 * \mathrm{Y} 1(-1)+0.0775 * \mathrm{Y} 2(-2) \\
& \mathrm{Y} 2=0.0369 * \mathrm{Y} 1(-1)+0.6177 * \mathrm{Y} 2(-1)+0.2820 * \mathrm{Y} 2(-2)
\end{aligned}
$$

Fourth indicator Y4 - Petroleum imports, mln $\mathrm{t}$ is given in table 5.

Petroleum imports, $m \ln t$

\begin{tabular}{|c|c|c|c|c|c|c|c|c|c|}
\hline Year & 2006 & 2007 & 2008 & 2009 & 2010 & 2011 & 2012 & 2013 & 2014 \\
\hline Table & 15,5 & 16,8 & 18,30 & 21,90 & 23,30 & 24,60 & 25,10 & 25,70 & 26,30 \\
\hline Forecast & - & - & 19,34 & 21,53 & 23,17 & 24,42 & 25,32 & 25,93 & 26,29 \\
\hline
\end{tabular}

Continuation of Table 5

\begin{tabular}{|c|c|c|c|c|c|c|}
\hline Year & 2015 & 2016 & 2017 & 2018 & 2019 & 2020 \\
\hline Table & 26,70 & - & - & - & - & - \\
\hline Forecast & 26,68 & 26,68 & 24,05 & 24,0 & 23,14 & 22,51 \\
\hline
\end{tabular}

Forecasted consumption patterns and gas such important indicators as gas, everything billion $\mathrm{m}^{3}$ gas consumption, everything billion $\mathrm{m}^{3}$, import of gas, everything billion $\mathrm{m}^{3}$ oil imports, total mln tons. The authors were built predictive models and developed guidelines and conclusions on possible scenarios for the development of the gas system in Ukraine's energy balance. Using group method of data handling for the construction of gas consumption forecasting scenarios enabled to view advanced options for the future development of energy sector in Ukraine for 5 years and made it possible to see clearly at that scenario may evolve gas sector in Ukraine and were forecasted and mentioned most important strategic key energy indicators.

Conclusions. Through analysis of the dynamics of gas consumption in Ukraine and analysis of such important indicators as gas, everything billion $\mathrm{m}^{3}$ gas consumption, everything billion $\mathrm{m}^{3}$, import of gas, everything billion $\mathrm{m}^{3}$ oil imports, total, mln tons - were built predictive models in the gas by using group method of data handling for the above indicators and made the following results:

- forecasted the growth of gas production, from 21,5 billiom $\mathrm{m}^{3}$ in 2006 to 25,86 billiom $\mathrm{m}^{3}$ in 2020;

- forecasted the decreasing of consumption of gas from 75,1 млрд. $\mathrm{m}^{3}$ in 2006 to 72,62 billiom $\mathrm{m}^{3}$ in 2020;

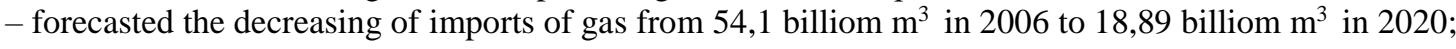

- forecasted the growth of petroleum imports from 15,5 mln $\mathrm{t}$ in 2006 to 28,23 $\mathrm{mln} \mathrm{t}$ in 2020 .

\section{References:}

1. Autonomiv A.B. World Energy: The state scale, perspective, sustainability, environmental issues, price dynamics of energy resources / A.B. Autonomiv // Power Station. - 2013. - № 5. - 55-64 p.

2. Ivahnenko A.G. Adoption decisions based on self-organization / A.G. Yvahnenko, Y.P. Zaichenko, V.D. Dimitrov. M. : Sov. Radio, 1976. -280 p.

3. Volkov A.M. Energy conservation, efficiency and economy of fuel and energy complex of Ukraine in general // Energy policy / A.M. Volkov, B.E. Popov, O.D. Protsenko, S.A. Potryasov. - 2009. - № 1. - 31-34 p.

4. Bashmakov I.A. Regional policy to increase energy-efficiency effect from problems to solutions. - M. : TSENEF, 2006. - 192 p.

5. Batyschev V.E. Energy Saving / V.E. Batyschev, B.G. Martinenko, S.L. Rozshukiv, J.M. Shchelokov. - Ekaterinburg, 2014. $-304 \mathrm{p}$.

6. Bokserman Y.I. Gas in the structure of world power industry: resources production, markets Agricultural Art Peck / Y.I. Bokserman, A.A. Beschinsky, V.I. Likhachev. - 2008. - № 3-4. - C. 42-50. 
7. Gordeev O.G. Status and prospects of development of the oil and gas industry // Oil Industry. - 2003. - № 1. P. 4-7.

8. Dmitrievsky A.N. Natural gas in the XXI century / A.N. Dmitrievsky // Oil Industry. - 2002. - № 12. - p. $14-17$.

9. Klimov G.N. Prospects of energy use of gas / G.N. Klimova, V.M. Litvak, I.Jaworski // Industrial Energy, 2012. № 8.

10. Kotler V.R. Primary energy consumption and fuel consumption structure in the world / V.R. Kotler // Electric stations. -2002 . - № 7. - S. 71 .

\section{References:}

1. Autonomiv, A.B. (2013), «World Energy: The state scale, perspective, sustainability, environmental issues, price dynamics of energy resources», Power Station, No. 5, pp. 55-64.

2. Ivahnenko, A.G., Zaichenko, Y.P. and Dimitrov, V.D. (1976), Adoption decisions based on self-organization, Sov. Radio, Moscow, 280 p.

3. Volkov, A.M., Popov, B.E., Protsenko, O.D. and Potryasov, S.A. (2009), «Energy conservation, efficiency and economy of fuel and energy complex of Ukraine in general», Energy policy, No. 1, pp. 31-34.

4. Bashmakov, I.A. (2006), Regional policy to increase energy-efficiency effect from problems to solutions, TSENEF, Moscow, $192 \mathrm{p}$.

5. Batyschev, V.E., Martinenko, B.G., Rozshukiv, S.L. and Shchelokov, J.M. (2014), Energy Saving, Ekaterinburg, 304 p.

6. Bokserman, Y.I., Beschinsky, A.A. and Likhachev, V.I. (2008), Gas in the structure of world power industry: resources production, markets Agricultural Art Peck, No. 3-4, pp. 42-50.

7. Gordeev, O.G. (2003), «Status and prospects of development of the oil and gas industry», Oil Industry, No. 1, pp. 4-7.

8. Dmitrievsky, A.N. (2002), «Natural gas in the XXI century», Oil Industry, No. 12, pp. 14-17.

9. Klimov, G.N., Litvak, V.M. and Jaworski, I. (2012), «Prospects of energy use of gas», Industrial Energy, No. 8.

10. Kotler, V.R. (2002), «Primary energy consumption and fuel consumption structure in the world», Electric stations, No. 7 , pp. 71.

STEPASHKO V.S. - PhD in Engineering science, Prof. of Kyiv Polytechnic Institute named after Ihor Sikorskyy.

TRACHUK A.R. - postgraduate student of Kyiv Polytechnic Institute named after Ihor Sikorskyy.

The article was submitted on 08.01.2017. 